This item was submitted to Loughborough's Research Repository by the author.

Items in Figshare are protected by copyright, with all rights reserved, unless otherwise indicated.

\title{
Costs of urban utility water connections: excessive burden to the poor
}

PLEASE CITE THE PUBLISHED VERSION

http://dx.doi.org/10.1016/j.jup.2007.06.002

PUBLISHER

(c) Elsevier

VERSION

AM (Accepted Manuscript)

LICENCE

CC BY-NC-ND 4.0

REPOSITORY RECORD

Kayaga, Sam, and Richard Franceys. 2019. "Costs of Urban Utility Water Connections: Excessive Burden to the Poor”. figshare. https://hdl.handle.net/2134/9951. 
This item was submitted to Loughborough's Institutional Repository (https://dspace.lboro.ac.uk/) by the author and is made available under the following Creative Commons Licence conditions.

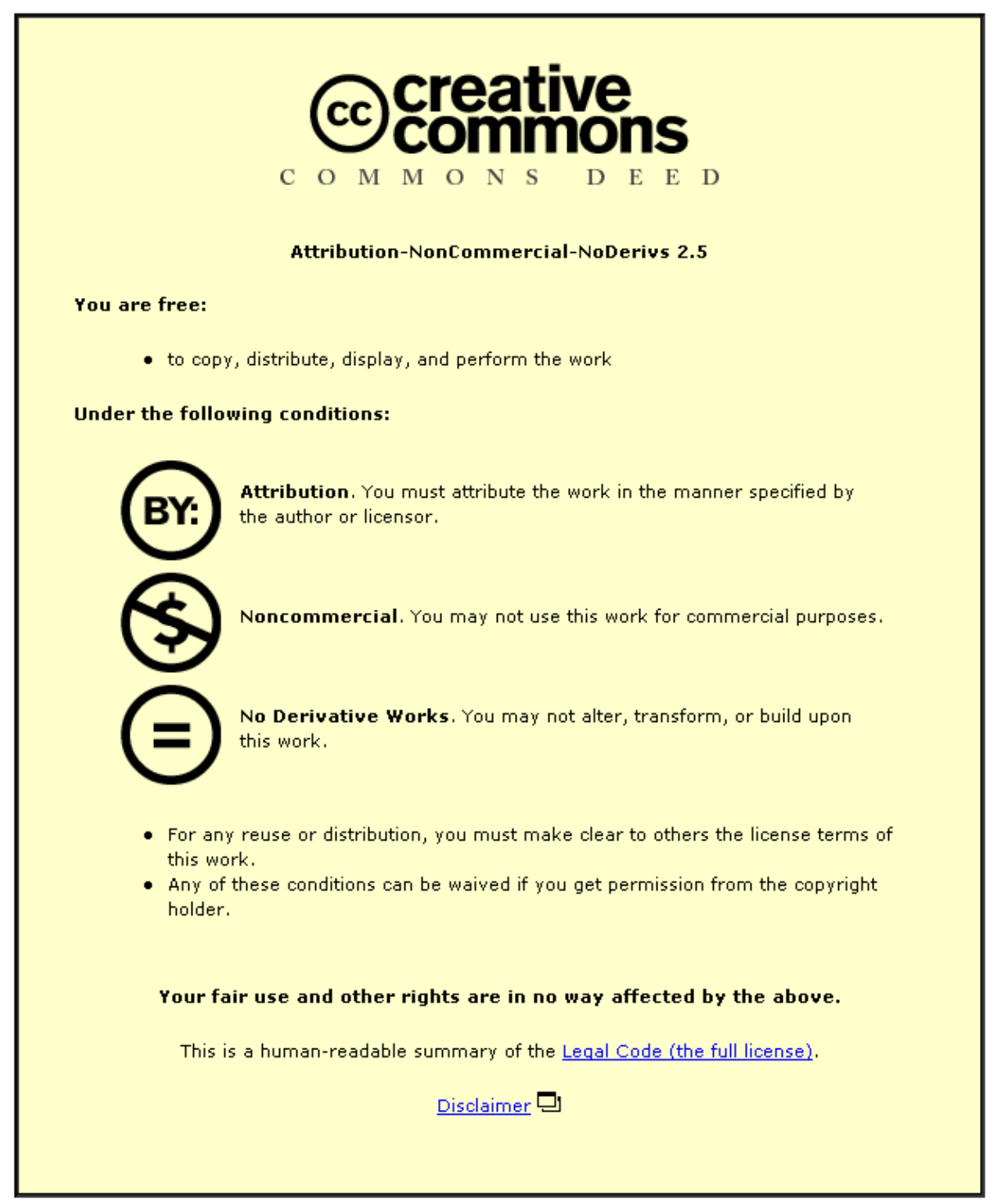

For the full text of this licence, please go to: http://creativecommons.org/licenses/by-nc-nd/2.5/ 


\title{
Costs of urban utility water connections: Excessive burden to the poor
}

\author{
Sam Kayaga ${ }^{a, *}$, Richard Franceys ${ }^{b}$ \\ ${ }^{a}$ Water, Engineering and Development Centre (WEDC), Loughborough University, Loughborough, Leicestershire LE11 $3 T U, U K$ \\ ${ }^{\mathrm{b}}$ Institute of Water and Environment, Cranfield University, Silsoe, Bedfordshire $M K 454 D T_{\lambda} U K$ \\ Received 22 December 2006; received in revised form 29 June 2007; accepted 29 June 2007
}

\begin{abstract}
A global research programme was undertaken to investigate the actual costs and charges of obtaining a water connection in urban areas. Drawing from the Uganda case study, this paper will contribute to the understanding of the enormity of the barriers of the connection process and costs levelled against the urban poor, and the importance of programmes and pricing structures for enabling access to the water supply systems. The researchers found a mean cost of new water connection of US\$500 (median of \$197). This is unaffordable for \$2 per-day-households, which are therefore unable to access the benefits from piped water services.
\end{abstract}

(C) 2007 Published by Elsevier Ltd.

Keywords: Costs; Urban poor; Water utility connection

\section{Introduction}

It is estimated that up to $37 \%$ and $57 \%$ of the urban population in Africa and Asia respectively are not directly served by piped water supply (WHO/UNICEF, 2000). Usually, the unserved are the lowest-income households, categorised as the urban poor, living in multi-occupancy tenements or compounds, in slums, shanties, unplanned and illegal settlements. The urban poor usually rely on water vendors, paying ten to twenty times as much per unit volume as the urban, pipe-connected rich who therefore capture most of the benefits of subsidised water. Some of the reasons advanced by urban water utilities for failing to serve the urban poor are the: (i) high costs involved in extending services to low-income settlements due to poor infrastructure planning and difficult topography in those areas of the city; (ii) illegal status of the low-income settlements; (iii) low ability to pay for the connections; (iv) low ability to pay the volumetric water rates; and (v) transient nature of residents of low-income settlements. Where lowincome households are not connected to the piped water

\footnotetext{
* Corresponding author. Tel.: +44 1509 228743; fax: +44 1509211079.

E-mail addresses: s.m.kayaga@Lboro.ac.uk (S. Kayaga),r.w.a.franceys@ cranfield.ac.uk (R. Franceys).
}

supply the poor cannot benefit from the convenience and health benefits of potable water, or from the lower costs arising from economies of scale, nor in price terms from cross-subsidies in the tariff structure.

This paper describes the Ugandan component of a global research study, 'Charging to Enter the Water Shop?', that investigated the actual costs of water connections to the urban poor. The research title alludes to the analogy of customers being charged a share of the fixed asset costs to enter a supermarket. Such a barrier to entry would be unacceptable in the retail sector and this research investigated just how much it costs to enter the water shop and questioned whether that is a fair and appropriate manner for recovering those costs. The study, carried out in a metropolitan and secondary city in each of four countries: Ghana, India, the Philippines and Uganda in 2004, was funded by the UK Department for International Development (DFID) under the Knowledge and Research Contract R8319. The objective of study, which was coordinated by Cranfield University, was to provide verifiable data on connection charges and costs to policy makers, regulators and utilities in low- and middle-income countries so as to enhance their understanding of need to reduce or perhaps remove the connection charges altogether, thus changing the common policy of 'charging to enter the water shop' (Franceys, 2005). 
The argument for changing the policy is that the poor benefit most from accessing clean water at an affordable consumption charge, having first achieved household or group water connections through differentiated tariffs and mains extensions. Such consumers usually have to survive on less than $\$ 2$ per day and typically consist of between $20 \%$ and $50 \%$ of the 2270 million population urban areas in low- and middleincome countries (UN ESA, 2004). Because of this level of poverty the poor are unable to build up any reasonable level of capital to invest in the major one-off payments typically required for connections, often charged at several hundred dollars. There is evidence to suggest that many categorised as poor are able to pay small on-going charges at a level similar to the cost of supplying water.

\section{The research problem}

There has been much discussion of affordability-to-pay, willingness-to-pay and tariff structures for water utilities in low- and middle-income countries. However, most of this discussion has concentrated on the volumetric "consumption charges' ${ }_{\Lambda}$ part of the tariff structure, de-emphasising the importance of 'connection charges'. At present there is only a limited available literature on connection charges, as opposed to consumption tariffs where there has been considerable research (e.g. Collingnon and Vezina, 2000; Kariuki and Schwartz, 2005; Pocock, 2002). At present there is only a limited available literature on connection charges, as opposed to consumption tariffs where there has been considerable research. As one example, the International Water Association in its research (Pocock, 2002) considered the role of price subsidy "a complex issue", price elasticity "a complex topic", and the effect of rising-block and cost reflective tariffs "inconsistent between communities". However it, along with much of the literature regarding water tariffs, does not address the specific problem of connection charges which are necessarily a precursor to accessing volumetric subsidies.

One driver for a reconsideration of connection charges has been the contractual requirement placed upon several of the international private operators to achieve specified, often $100 \%$, levels of service coverage. As these operators have moved beyond conventional housing areas into unplanned and peri-urban areas they have found that households are unable to connect, even when the pipes arrive in their street. The contractual requirement is then reinforced by the revenue requirement to be able to generate revenue to pay for the new fixed assets as well as limiting illegal connections to the extended network. For example, the connection charges in Buenos Aires, in the earlier period of that concession were equivalent to US $\$ 415$ for water and $\$ 606$ for sewerage. This was unaffordable for the lower-income population and the take-up of new connections slowed even though households were legally bound to connect when the network passed their homes. Through negotiations, the connection charge was reduced to $\$ 120$ for both services, with payment of that amount amortised over several years. The shortfall in revenue was made up with a universal charge on all other customers of $\$ 4$ per bi-monthly billing.
This, along with other supporting measures, led to a significant increase in connections to the poor (Franceys, 2005). The poor in areas worldwide where the private sector is not yet involved also need to benefit in the same way.

Connection charges, i.e. the fees the utility charges, and connection costs, i.e. the physical costs households have to pay for plumbing materials such as pipes are often beyond the ability to pay of poor users, if at all the water mains are in easy reach. High connection charges often appear to be designed as a barrier to entry, to limit demand on a precarious water system. An alternative explanation is that they maximise illegal on-selling of water to vendors by utility staff (McIntosh, 2003). Addressing the implications of connection charges and costs is therefore critical to enable the poor to acquire the benefits of public investment.

In the recent past, a paper presented during the 2005 Conference on Private Participation in Infrastructure in SubSaharan Africa presented data from 26 countries from the region, which showed that piped water systems exclude $40 \%$ of the poorer sections of the population (Diallo and Wodon, 2004; Estache, 2005). This study found that whereas $34 \%$ of the households falling in the lowest quintile in terms of income levels had access to improved water sources (i.e. in form of public water points), none of the households were directly connected to piped water systems (Diallo and Wodon, 2004). Another recent study conducted in Senegal showed that expansion of the reticulation network through private sector participation has not benefited the two lowest quintiles of the population (Boccanfuso et al., 2005). The findings of these studies in Africa are collaborated by a similar one conducted in Bolivia, which found that, in general, marginal benefit incidence is higher for the poor than for the non-poor in education, but is lower in the case of access to infrastructure services such as water and sanitation (Ajwad and Wodon, 2001).

Several studies have been conducted on delivering and maintaining utility services to the poor (e.g. Lovei et al., 2000); the benefits of urban connections to services (Shi, 2000); and on differentiating service levels in order to ensure affordable continuous water delivery to the poor (e.g. Sansom et al., 2004). The benefits can be significant, in economic terms and in health terms. One study reports that child mortality fell by $24 \%$ in the poorest municipalities as a result of increased household connections in Argentina (Galiani et al., 2002). A study carried out in Asia (Weitz and Franceys, 2002) highlighted findings from focus groups discussions in which women reported the benefits that are achievable as a result of gaining household connections in poor areas, following regulatory facilitation of operators. Benefits cited by householders in Jakarta, Indonesia and Manila, the Philippines included productive use of water $r_{\bar{\lambda}}$ reduced household expenditure on water services $\overline{\bar{\lambda}}_{\bar{\lambda}}$ time freed for other household chores; relief of stress from queuing; peace of mind arising out of reliability of water supply; and scarce household funds freed for other household needs.

On the other hand, Estache et al. (2000) take an economist's overview of the costs and benefits of improved and formalised connections to the poor for various types of network utilities in Latin America, referring to the challenge of getting connections costs correct, without going into the practical details of that for 
the water sector. None of the studies reviewed focus upon the challenge utilities have in sorting out connection charges. As a result, there is inadequate verifiable knowledge and understanding amongst government water utilities regarding the specific role of connection charges, which when linked to physical connection costs, make household connections unaffordable to the poor. This is a specific problem which has tended to be lost in the larger issues such as tariff policy, public private partnerships and regulation but which has a direct impact on the poor with potential for early benefits. It is hoped that the results of the research on the magnitude of charges and costs of water connections, and their perceived effect on the urban poor households' ability to connect onto the urban water services will go a some way to filling this knowledge gap.

\section{Research methodology}

The initial stage of the global research programme, reported elsewhere (Franceys, 2005), entailed a survey of published and grey material to obtain data on existing documented connection charges and costs as well as a global postal survey of utilities to determine official connections charges. Following the global overview of data, and the initial analysis of the key factors, two utility-serviced areas were selected from each of the participating countries of Ghana, India, the Philippines and Uganda: a city with a population of at least one million people, and a secondary town with a population of less than 500,000 people. Using a case-study approach, data was obtained on the connection process as well as actual connection charges and costs from utility customers who had connected in the previous six months. The procedures undertaken to obtain data in all the participating cities followed the general pattern outlined below:

- review of customer database in the service areas to extract applications from households for water connections in the past one year, and newly connected customers in the past six months;

- semi-structured interviews with selected newly connected customers, to explore the real costs for obtaining a new connection;

- semi-structured interviews with selected applicants who had not been connected in the past six months, to explore the reasons for not connecting, what barriers they experienced, and what coping strategies they adopted;

- focus group discussions with selected potential customers, direct and indirect customers in low-income settlements on their experiences, fears, and perceptions on new connections costs and procedures; and

- semi-structured interviews with senior utility managers on their perceptions of the costs of connections, and its implications on the utility and the potential customers.

\section{The water connection process}

This section documents an example of a worst-case scenario of a general connection process as described by the research respondents from the participating utilities in the four countries. The purpose of describing the process in detail is not to suggest that the utilities are in any way particularly deficient in their processes but rather to show what a significant hurdle obtaining a water connection can be to a daily-paid occasional labourer perhaps renting a room or two on a barely 'legal' housing development. But it is precisely these households who can benefit most dramatically from the convenience and lower consumption cost of a suitable connection. The connection process varies, depending on the policy framework of the participating utility. Even under the same policy framework, there are variations in the way the policy is applied in the service areas and, sometimes as the service interface staff deals with various customers.

The starting point of the process usually requires acquisition of the Application Form which can require a formal fee, with the potential for an informal request or 'thank you' payment. Completing this form may require a payment to a local councillor to gain appropriate approval, payment to the landlord for proof of land ownership and/or payment for an approval letter from the pipe owner/community water association who may well have paid for an 'alternative' mains extension. Submitting the completed Application Form with its necessary supporting documents can require payment of a Connection Fee which might include a substantial part of the costs of physical connection outlined below or may simply be an administrative fee or a contribution to mains extension costs. At this stage there is again the possibility of having to pay 'speed money' to gain timely acceptance of the application as well as the on-going opportunity costs of the time taken to travel to the appropriate water utility office which may well be in the centre of the city. Submission of the application might well trigger a visit by the utility surveyor to check the location and the proximity to the water main which can require an additional survey fee in addition to associated costs of perhaps paying for transport for the surveyor as well as snacks and encouragement money.

Following the acceptance of the application, which again might require 'speed money', there is the need to obtain the mains-tapping or ferrule connector, the communication pipe, meter and stop-cock, perhaps from an 'approved' supplier (where costs could be higher) or perhaps included as part of the connection fee. Next are the labour charges for trench digging, probably including snacks for water utility staff working overtime or at weekends to install the pipe-work to the satisfaction of an inspector who might also require transporting or compensation. If the householder is 'unlucky', the mains to connect inte will be on the other side of the surfaced roadway and therefore the householder will be liable to 'road-cutting charges'. These charges cater for reinstatement to a suitable standard, which might require approval by a different, road, inspector. The final meter installation and/or counting of taps to determine tariff levels could also require a final visit with associated informal costs. Or if suitable payment is made this visit can be delayed for a period to allow for un-metered consumption until the meter installer/reader 'has time to install the meter'. 
Some households, though probably not the target lower-income households, may want to add to these costs the actual inhouse pipe-work and sanitary fittings. Furthermore, depending upon the quality and hours of supply, they may consider the additional costs of small pumps to suck the water out of the mains, ground tanks to store the water when it arrives intermittently, and/or potentially an additional pump to a roof level tank to give the convenience of reasonable pressure in the taps in a variety of household locations.

All of the above need financing which implies additional costs of borrowing for low-income consumers. Is it any wonder that the poor have to rely upon vendors or neighbours charging several times more than the official volumetric lifeline charge?

\section{Empirical data from the Uganda case study}

Fieldwork was carried out in January 2004 in two of Uganda's largest towns of Jinja (2002 population of 413,937) and Kampala (2002 population of 1,208,504) (Government of Uganda, 2004). We targeted households that had been connected during the period beginning on 1 July, 2003 to 31 December, 2003. The total number of premises that were connected onto the water reticulation system in Jinja were 76 , of which 32 were industrial, commercial and institutional premises. Non-household premises were removed from the sample, reducing the valid sample to only 46. Although all these households were approached for interviews, only 20 households were fully responsive. The main cause of non-responsiveness was the non-availability of heads of household at the time of the fieldwork.

On the other hand, 3863 new connections were implemented during the same period in Kampala Water Supply Area, of which only 3284 were for households. Owing to the high geographical spread of these households, we opted for cluster sampling, in which we targeted newly connected households in two of the six service zones (i.e. 1086 households). A 5\% random sample was extracted using SPSS programme, equating to a sample of 54 households in Kampala. Similar to the situation in Jinja, quite a few of the household heads were not available for the interviews - we achieved a response rate of $42 \%$.

Next, four focus group discussions (two in Jinja and two in Kampala) were facilitated in four low-income settlements to find out from those without household connections what barriers they had experienced. In line with case study methodology, we made contacts (well in advance) with community leaders in the representative low-income locations, and requested them to purposefully select participants for the focus group discussions. The criteria for selection included (i) residents of a high standing in the community; (ii) interest in development issues in the area; (iii) a balanced mixture of men and women; (iv) inclusion of a couple of residents whose households are connected onto the water distribution network; and (v) the group with numbers between 6 and 15. A total of 56 people participated in focus group discussions, 28 in Jinja (12 women and 16 men); and 28 in Kampala (19 women and 9 men). Participants were facilitated to discuss perceived barriers of connecting onto the utility distribution network. In the same focus groups, participants who had water connections talked through the process they underwent, and what total costs it amounted to. At separate occasions and places, interviews were also held with several applicants who had failed to get water connections. Finally, the perceptions and plans of the water utility senior staff were also elicited through semi-structured interviews.

The official provider of water to the main urban centres of Uganda, composed of $62 \%$ of the total urban population in the country, is the National Water and Sewerage Corporation (NWSC), a public 'corporatised' utility which over the past ten to fifteen years has benefited from significant reform inputs, including technical assistance, capacity-building, service contracts through international operators, as well as skilled leadership (National Water and Sewerage Corporation, 2003). However, prior to this fieldwork being undertaken in 2004 the Uganda National Household Survey (1999/2000) reported that only $7 \%$ of the urban population had access to individual in-house pipe connections (only $1.2 \%$ of the poorest households, by quintile) with an additional $9.4 \%$ accessing through piped yard taps (Uganda Bureau of Statistics, 2001). This service level is collaborated by WHO/UNICEF Joint Monitoring Programme for Water Supply and Sanitation, which estimated that the number of households connected to the water supply system reduced from $24 \%$ in 1990 to $7 \%$ in 2004, mainly due to minimal service extensions compared to the urban population growth (WHO/UNICEF, 2006). It should however be noted a large number of households in the larger towns serviced by NWSC obtain water services through public standpipes, which raise the service coverage in these towns, compared to the situation in the smaller towns.

\subsection{Socio-economic data}

Table 1 shows a summary of socio-economic status of the sampled utility customers who were connected in the previous six months. The results in Table 1 show that most of the respondents $(75 \%)$ had a formal education of at least eight years, and half the sample reported to have had over 13 years of formal education. It might be pointed out that the research respondents are not a representative sample of the population of Uganda, whose literacy level is merely 68\% (UNDP, 2003). This asymmetry in education levels is an indicator of affluence characteristic of the typical water utility customers in the country.

\subsection{Survey results on the connection costs and the process}

Table 2 shows a summary of the profile of direct and indirect costs incurred by the interviewed customers in the process of obtaining a water connection. These costs are subsequent to the 1998/99 reduction of connection fees by an average of $50 \%$. However they are distorted, to the extent to which they are relevant to the urban poor, in that some of the very high costs represent individual households in low-density 
Table 1

Summary of socio-economic characteristics of respondents

\begin{tabular}{|c|c|c|}
\hline \multirow[t]{2}{*}{ Indicator } & \multirow[t]{2}{*}{ Category } & \multirow{2}{*}{$\begin{array}{l}\text { Frequency } \\
\text { Valid cases }=43 \\
\end{array}$} \\
\hline & & \\
\hline \multirow[t]{2}{*}{ Gender } & Female & $22(51 \%)$ \\
\hline & Male & $21(49 \%)$ \\
\hline \multirow[t]{3}{*}{ Level of education } & $\begin{array}{l}\text { Primary level (up to } 7 \text { years } \\
\text { of formal education) }\end{array}$ & $11(26 \%)$ \\
\hline & $\begin{array}{l}\text { Secondary level ( } 8-13 \text { years } \\
\text { of formal education) }\end{array}$ & $11(26 \%)$ \\
\hline & $\begin{array}{l}\text { Tertiary level (over } 13 \text { years } \\
\text { of formal education) }\end{array}$ & $21(49 \%)$ \\
\hline \multirow[t]{2}{*}{ Tenure of property } & Owner-occupied & $36(84 \%)$ \\
\hline & Rented & $6(14 \%)$ \\
\hline \multirow[t]{4}{*}{ Occupation } & Business & $13(30 \%)$ \\
\hline & $\begin{array}{l}\text { Farming (subsistence } \\
\text { cultivation or animal rearing) }\end{array}$ & $6(14 \%)$ \\
\hline & Housewives & $5(12 \%)$ \\
\hline & Professionals & $19(44 \%)$ \\
\hline \multirow[t]{3}{*}{ Household size } & $1-5$ people & $7(16 \%)$ \\
\hline & $6-10$ people & $28(65 \%)$ \\
\hline & Over 10 people & $8(19 \%)$ \\
\hline \multirow[t]{3}{*}{$\begin{array}{l}\text { Estimated household } \\
\text { expenditure }^{\mathrm{a}}\end{array}$} & $\begin{array}{l}\text { Less than Uganda } \\
\text { Shillings (Ush) 300,000 } \\
\text { (US\$170)/month } \\
\text { (Low income) }\end{array}$ & $8(19 \%)$ \\
\hline & $\begin{array}{l}\text { Between Ush300,001 and } \\
1,200,000 \text { (US } \$ 170-683) / \text { /month } \\
\text { (Middle income) }\end{array}$ & $20(47 \%)$ \\
\hline & $\begin{array}{l}\text { Over Ush } 1,200,000 \\
\text { (over US } \$ 683) / \text { month } \\
\text { (High income) }\end{array}$ & $14(32 \%)$ \\
\hline
\end{tabular}

Source: survey data, January 2004.

${ }^{a}$ Uganda Shillings 1757 was equivalent to 1 US dollar at the time of fieldwork conclusion.

peri-urban areas installing a considerable length of new pipe to meet their personal needs but which they can recoup by onselling connections to new neighbours as the housing density in the area increases.

As can be seen from the 'range' column in Table 2, the costs incurred by respondents varied very significantly from one customer to another. The costs before approval of the application included payment for an application form; costs for photocopying the necessary documents; costs for taking passport size photographs required for the application form; charges for obtaining a letter of introduction from the neighbourhood committees and/or the landlord; charges for obtaining a letter of consent from the owner of the tertiary main; and processing of the sketch map showing the location of the property. Similarly, the costs incurred on surveying the site varied, depending on several factors. For instance, applicants with property in a green-field area required more input from the surveyor. Some respondents visited the utility office up to six times before their connection sites were surveyed, some of whom reportedly paid 'speed money' to hasten the process.

One would have expected the official connection fee charged by the utility to be uniform. This was not the case. Most respondents (65\%) reported to have paid an official connection fee of Uganda Shillings (Ush) 58,500 (US\$33). This
Table 2

Costs, in Uganda Shillings ${ }^{\text {a }}$, incurred on new connections in Jinja and Kampala

\begin{tabular}{|c|c|c|c|}
\hline Type of costs & Mean & Median & Range \\
\hline Costs prior to application & 1163 & 0 & 50000 \\
\hline Consent costs prior to application & 26044 & 2000 & 198500 \\
\hline Official connection charge & 67570 & 58500 & 158500 \\
\hline Survey charge & 250 & 0 & 10000 \\
\hline Survey costs & 2184 & 0 & 30000 \\
\hline Informal survey costs & 3029 & 0 & 50000 \\
\hline $\begin{array}{l}\text { Opportunity cost of application } \\
\text { and survey }\end{array}$ & 14753 & 400 & 300000 \\
\hline Informal application approval costs & 1207 & 0 & 35000 \\
\hline Informal connection costs & 465 & 0 & 20000 \\
\hline Road cutting costs & 10233 & 0 & 200000 \\
\hline Labour for trenching \& pipe-laying & 23222 & 9000 & 180000 \\
\hline $\begin{array}{l}\text { Snacks etc. for trenching \& } \\
\text { pipe-laying }\end{array}$ & 60858 & 0 & 2500000 \\
\hline $\begin{array}{l}\text { Opportunity cost of connection } \\
\text { process }\end{array}$ & 8302 & 0 & 90000 \\
\hline Cost of materials & 282842 & 121500 & 5800000 \\
\hline $\begin{array}{l}\text { Opportunity cost of obtaining } \\
\text { materials }\end{array}$ & 8188 & 2000 & 60000 \\
\hline Labour for connecting & 87576 & 0 & 2500000 \\
\hline Snacks etc. for connecting & 2783 & 0 & 34000 \\
\hline Opportunity cost of connecting & 55548 & 27500 & 240000 \\
\hline Costs of meter installation & 1860 & 0 & 40000 \\
\hline Costs for connection approval & 1062 & 0 & 20000 \\
\hline $\begin{array}{l}\text { Interest costs on borrowing for } \\
\text { new connection }\end{array}$ & 63567 & 0 & 2623000 \\
\hline $\begin{array}{l}\text { Additional costs for coping with } \\
\text { intermittent supplies }\end{array}$ & 273217 & 30000 & 4795200 \\
\hline \multirow{2}{*}{$\begin{array}{l}\text { Total costs associated with } \\
\text { the process }\end{array}$} & 878614 & 346000 & $11074100^{b}$ \\
\hline & (US\$500) & (US\$197) & (US\$6303) \\
\hline
\end{tabular}

Source: survey data, January 2004.

${ }^{\text {a }}$ Uganda Shillings 1757 was equivalent to 1 US dollar at the time of the fieldwork conclusion.

${ }^{\mathrm{b}}$ Connection components may not sum to totals due to unrecorded response/ 'non applicable' response to some component questions.

figure includes Value Added Tax at a rate of $17 \%$. However, 13 respondents $(30 \%)$, most of whom were in the smaller town Jinja, reported to have paid an extra amount of Ush30,000 (US\$17) as a deposit for consumption charges, bringing the total official amount required for connection charges to Ush88,500 (US\$50). Clearly, the policy on connection fees was not been enforced in a harmonised manner. Furthermore, most respondents were unaware of the breakdown of the charges.

Applicants who were required to lay their service line across municipal roads had to dig deeper in their pockets for road reinstallation charges, payable to the municipal authorities, and a receipt presented to the water utility as a prerequisite for getting into the utility's new connection programme. During the peak period when there were many outstanding new connections to be effected, payment of 'speed money' to key individual utility staff could bring one's scheduled date forward. This proposition would make economic sense, in view of the fact although $11 \%$ of the respondents spent up to one week for the new connection to be effected, when the mean length of the connection process across the whole sample was 104 days. 
According to the documented procedures, the applicant is required to purchase materials as per the requirement list drawn by the utility's new connection gang. Purchase of materials for the connection process made the largest contribution to the variance in total connection costs as reported by respondents. In the first instance, the procedures reportedly followed by respondents did not only vary from one customer to another, but also varied significantly from the standard procedure posted on the utility's website (http://www.nwsc.co.ug/ information.php). All respondents paid for connection materials such as pipes, ferrules, saddle pieces and stop corks. However, the amount paid and method of payment differed from one respondent to another. Some respondents purchased the materials by themselves, others paid to the utility staff or to third parties. Over $50 \%$ of respondents also spent on transport costs in preparation for, and in the process of, the actual connection.

On the actual date of effecting the connection, the utility was expected to make the connection onto the tertiary main and lay the communication pipe (which is usually 6 metres long), while the applicant was responsible for laying the service line. This meant that the applicant was expected to pay for all costs pertaining to the laying of the service line, such as provision of materials, as well as labour charges for excavating the trench, laying the pipeline, backfilling and compacting. For about $30 \%$ of respondents, there were separate costs reportedly incurred during the connection process such as provision of transport, meals, snacks and/or drinks to the labourers. Although the task was demarcated between the utility and the household, in most instances reported, all work was carried out by utility staff, who were privately paid for laying the service line.

Even after the connection was effected, seven respondents (17\%) reported to have paid some 'speed money' before they started enjoying benefits of piped water at home. Four respondents reportedly paid so that 'the gate valve may be turned on', prior to the water flowing to the household. On the other hand, three respondents reported to have paid the bribe so that their new connections could be fitted with a water meter, in order to 'avoid exorbitant flat rates levied by the utility'.

\subsection{Interviews with fully paid-up applicants, but not yet connected}

Examination of the new connections database in the two NWSC study areas showed a fast build up of number of approved applicants who were not yet connected onto the distribution network. Therefore, we deviated from the general methodology and sought to interview those applicants that had gone through most of the connection process and paid the connection fee, but had not been connected, to find out their barriers to entry. We interrogated the NWSC database and came across nine households in this category (two in Jinja and seven in Kampala). Owing to the fact that three households had not been updated on the NWSC Block-mapping system, we located only six households, for which only four heads were available for the interview. All the respondents in this category had fully paid the connection fee to the utility, and were in possession of official receipts. One respondent had paid the connection fee two years earlier, but had failed to pay the road re-instatement charges to the municipal authority. In addition to the connection fees paid to the utility a year earlier, two respondents had spent about Ush250,000 (US\$142) on materials. Furthermore, one respondent claimed to have paid road re-instatement charges to the municipal authority, while another had paid Ush200,000 (US\$114) for permission to connect off her neighbour's service line. However, the utility had not scheduled them for connection by the time of the survey.

The respondents claimed to have pestered the utility offices demanding for service connection. The utility officials blamed the delay on lack of customer meters, which are normally purchased through an international competitive bidding process. The respondents thought that they are not being told the truth. They suspected the staff could be selling the meters to customers. Alternatively, the staff might have been interested in bribes, but were not being open about it. Naturally, these respondents expressed intense frustration at the delay in the connection process.

Clearly, the cases described above are not typical of the existing situation in the study areas. There are outliers that highlight how difficult obtaining a water connection could become. The managers of NWSC were aware the difficulties applicants of new connection faced. In an interview with the NWSC Manager for Operations, he highlighted three basic problems: (i) high connection costs (in form of materials, labour, road reinstatement costs etc); (ii) inadequate awareness of procedures for new connections; and (iii) middle men $\Lambda_{\Lambda}$ escalate the cost of new connections and create a false impression of lengthy procedures. Indeed, the third point was corroborated by participants of focus group discussions in Kampala who confirmed the existence of former NWSC staff who still collect water rates from unsuspecting utility customers, as described in the next sub-section.

\subsection{Focus group discussions in the low-income settlements}

On the whole, findings from focus group discussions (FGDs) with residents of low-income settlements confirmed the results from the survey study, and in many cases assisted to clarify some points that had been left hanging. The total expenditure on obtaining a connection quoted by various participants of the FGDs ranged between Ush200,000 to 780,000 (US\$114-444). Both the longwinded procedure and the non-standardised, unpredictable nature of processing an application were confirmed by participants who had water connections. Owing to the fact that there were hardly any tertiary pipelines extended by the utility into low-income settlements, many of these customers had been connected onto their neighbours' service pipelines, after negotiated compensations had been paid. One of the disadvantages of such 'sub-connections' was that as more households are connected, the service lines become overloaded, and as a result supply low pressure to the end customers. The participants also highlighted a problem 
that is unique to utility customers residing in low-income settlements. Because there are hardly any road reserves where water pipelines are normally laid, applicants for new water connections had to negotiate with and pay all landowners through which their service lines were laid.

The utility's policy of obtaining a consumption deposit at the time of the connection featured as a barrier to obtaining individual connections in low-income settlements. According to the new connection policy in force at the time of the research, individual utility managers had the choice to demand for an advance deposit for consumption charges prior to a new connection. Because utility managers perceived residents of low-income settlements as unable to pay for the water bills, participants observed that they were most likely required to pay a deposit of Ush30,000 (US\$17) for a house connection or Ush100,000 (US\$57) for a public standpipe. Ironically, this advance deposit was rarely required from higher-income applicants.

Other important issues raised by participants included (i) the cumbersome, time-consuming and costly procedures for inspecting materials for the new connection; (ii) the difficulty faced by some applicants to obtain consent from their landlords; (iii) the lack of utility policies and procedures documented in native languages, that are understood by the majority; (iv) the high informal charges levied by members of staff at various levels of the connection process; and (v) the presence of former utility staff in the low-income settlements who tempted community members to opt for illegal connections.

\section{Post-research developments on the NWSC connection policy}

It is important to point out that this fieldwork was carried out in January 2004, during a state of change in which the NWSC was completely being turned around (Mugisha and Berg, 2006). Through a series of innovative change management programmes instituted by the new leadership since 1998, NWSC has been transformed from an organisation in a state of near bankruptcy, with losses of US\$0.4 million in 1998 to a vibrating utility with a surplus of US\$3 million in 2006 (Berg and Muhairwe, 2006). The change management programmes aimed, among others, at (Mugisha and Berg, 2006) (i) reducing accounts receivables and bad debts; (ii) improving financial performance through enhanced monitoring of managerial performance; (iii) evaluating and adjusting the tariff by reducing connection/reconnection fees and indexing the tariff against inflation; (iv) expanding the customer base by extending the pipe distribution network and introducing a new connection policy that provided connection materials to applicants within a limited distance from the tertiary main; (v) modernising information technology; and (vi) improving customer service.

This research supplemented the change management programme of NWSC, and provided well-researched data, used as a basis for well-grounded decision making. Therefore, soon after the fieldwork, the initial results were shared with
Table 3

Selected performance indicators for NWSC between 1998 and 2006

\begin{tabular}{lll}
\hline Performance indicator & Performance level \\
\cline { 2 - 3 } & 1998 & 2006 \\
\hline New connections per year & 3317 & 23312 \\
Total connections & 50826 & 148312 \\
$\begin{array}{l}\text { Percentage connections } \\
\quad \text { that are active }\end{array}$ & $63 \%$ & $94 \%$ \\
$\begin{array}{l}\text { Service coverage } \\
\text { Annual revenue (turnover) }\end{array}$ & $48 \%$ & $70 \%$ \\
\hline
\end{tabular}

Source: Berg and Muhairwe (2006).

NWSC management. A meeting was held with the Managing Director, the Manager, Corporate Services and Manager, Operations on 1 April, 2004. Subsequently, the National Water and Sewerage Corporation (NWSC) reviewed their connection policy in July 2004. Under the new policy, the customer pays a connection fee of Ush50,000 (US\$28), and NWSC provides all the pipes/fittings, and pays for all the costs of laying the communication pipe (i.e. up to the customer's meter), for a maximum distance of 50 metres (Isingoma, 2005). To cover these extra costs, a small surcharge was introduced onto the tariff, paid by all customers. New connections increased from 1200 to 2000 in the first year of implementing this new connection policy. In tandem with other far reaching change management programmes, this new connection policy has resulted into positive outcomes in service delivery, as manifested by trends in performance indicators shown in Table 3.

The big increase in the number of new connections (an increase of $600 \%$ in eight years) shown in Table 3 indicate $\lambda_{\lambda}$ there was a huge suppressed demand for new connections which the policy brought to light (Isingoma, 2005). Recently it has also meant that NWSC has had to ration new connections as there was insufficient capacity to meet the suppressed demand (Tumuhairwe, 2006). In addition, the water distribution main pipeline has been extended by $1300 \mathrm{~km}$ during the same period (1998 to 2006), resulting in an increase of $52 \%$ in network coverage (Berg and Muhairwe, 2006). However, it is not yet clear if these changes have been benefiting the poor as it is likely that the majority of households in unserved, informal housing areas and slums do not lie within $50 \mathrm{~m}$ of a water main.

\section{Conclusions}

The results of the Uganda research demonstrate the substantial and unpredictable nature of the costs involved in obtaining a new water connection, costs which are often too risky as well as unaffordable. The poor, almost by definition, are unable to build up such capital sums. A mean of US\$500 with a median of US\$197 for a 'two dollar a day' households, service for whom must be the goal of a public water supply, is too high. Many more water utilities need to adjust their new connection policies, reducing charges and including costs in the type of 'all-in' approach now being developed by NWSC, with distribution costs depreciated over several years. 
Extending services to the low-income settlements in urban areas is a critical success factor for increasing access of the urban poor to the water services. Given the intense capital costs associated with conventional services, utilities might need to adopt interim measures to reduce the huge service gap, and provide lower service levels that utilise appropriate technologies, as advocated by Sansom et al. (2004). Furthermore, utilities need to revisit their cross-subsidy policies, and develop mechanisms to detect and stamp out corruption tendencies exhibited by some sections of their staff. These issues have deliberately been addressed by the NWSC change management (Berg and Muhairwe, 2005; Mugisha and Berg, 2005). Such measures will ensure that the urban poor receive improved drinking water services, for which they are able and willing to pay, and avoid the exploitative alternative service providers. Additionally, water utilities need to learn from the cable television and mobile phone operators who seem to have perfected the art of segmenting their customer base and differentiating their services to cater for all types of customers across the spectrum of the customer base.

\section{Acknowledgements}

This document is an output from a project funded by the UK Department for International Development (DFID) for not necessarily those of DFID. The authors would like to stress their appreciation of the efforts of all members of the international research team. Special gratitude goes to Lillian Mpabu-

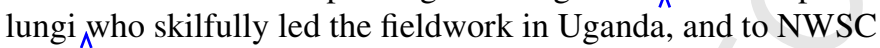
Managing Director, Manger ${ }_{\Lambda}$ Corporate Services, $\wedge^{\text {and Area }}$ Managers of Jinja and Kampala for their support.

\section{References}

Ajwad, M., Wodon, Q., 2001. Do local governments maximize access to public services across areas: A test based on marginal benefit incidence analysis, National Statistics Institute of Bolivia (UDAPE) and World Bank, available at http://wbln0018.worldbank.org/LAC/LACInfoClient.nsf/Sector/By+Sector_ Theme_LCSPR/7CCAAF6912337D5A85256AE80069D591?OpenDocument

Berg, S.V., Muhairwe, W.T., 2006. Healing an organisation: high performance lessons from Africa, Unpublished review paper for Public Utility Research Centre, University of Florida Warrington College of Business, Florida, USA, available at http://bear.cba.ufl.edu/centers/purc/primary/documents/ Healing_High_perf_lessons0906.pdf, accessed on 21 December 2006.

Boccanfuso, D., Estache, A., Savard, L, 2005. A poverty and inequality assessment of liberalization of water utility in Senegal: A macro-micro analysis, Groupe de Recherche en Économie et Développement International (GRÉDI) Working Paper 05-13. Université de Sherbrooke, Québec.

Collingnon, B., Vezina, M., 2000. Independent Water and Sanitation Providers in African Cities. World Bank Water and Sanitation Program, Washington DC. programme, which has already started paying dividends the benefit of developing countries. The views expressed are
Diallo, A., Wodon, Q., 2004. Access to Network-Based Infrastructure Services in Africa: Benefit and Marginal Benefit Incidence Analysis. The World Bank, Mimeo.

Estache, A., 2005. What do we know about Sub-Saharan Africa's infrastructure and impact of its 1990s reforms? Conference on Private Participation in Infrastructure in Sub-Saharan Africa, available at http://www.ppiaf.org/ FinalReportActivityPages/PPIAfricaConference/Africa report v4 Estache paper.pdf

Estache, A., Gomez-Lobo, A., Leipziger, D., 2000. Utilities 'privatization' and the poor's needs in Latin America: Have we learned enough to get it right? Infrastructure Development, London.

Franceys, R., 2005. Charging to Enter the Water Shop? Determining the Charges and Costs of Urban Connections for the Poor. Final Report to DFID, Institute of Water and Environment, Cranfield University.

Galiani, S., Gertler, P., Schargrodsky, E., 2002. Water for Life: The Impact of the Privatization of Water Services on Child Mortality. Center for Research on Economic Development and Policy Reform, Stanford.

Government of Uganda, 2004. Population and Housing Census 2002. Uganda Bureau of Statistics, Kampala.

Isingoma, D., October 2005. Linking Tariff Structure Changes to Improved Utility Performance in Uganda. In: Water Utility Management International. IWA, London.

Kariuki, M., Schwartz, J., 2005. Small-scale Private Service Providers of Wa- Q1 ter Supply and Electricity-A Review of Incidence, Structure, Pricing and Operating Characteristics. Policy Research Working Paper 3727. World Bank, Washington DC.

Lovei, L., Gurenko, E., Haney, M., O'Keefe, P., Shkaratan, M., 2000. Main-

McIntosh, A.C., 2003. Asian Water Supplies: Reaching the Urban Poor. Asian Development Bank, London.

Mugisha, S., Berg, S., 2006. Turning around struggling state-owned enterprises in developing countries: The Case of NWSC-Uganda. Available at http://bear.cba.ufl.edu/centers/purc/publications/documents/Struggling state-owned_enterprises10-06.pdf (accessed on 26 June, 2007).

National Water and Sewerage Corporation, 2003. NWSC Corporate Plan: July 01, 2003-June 30, 2006. Uganda NWSC, Kampala.

Pocock, M., 2002. Water pricing as a Key Element in a Sustainable Strategy. International Water Association, MIA Specialist Group, London.

Sansom, K., Franceys, R., Njiru, C., Kayaga, S., Coates, S., Chary, S., 2004. Serving All Urban Consumers. Published research report. WEDC, Loughborough University, Loughborough.

Shi, A., 2000. How access to urban potable water and sewerage connections affects child mortality. Working Papers-Environment. World Bank, Washington DC.

Tumuhairwe, S., 2006. personal communication with NWSC Area Manager. Entebbe, Uganda.

Uganda Bureau of Statistics, 2001. Uganda National Household Survey, 1999/ 2000. UBOS, Entebbe.

UN ESA, 2004. World population prospects: The 2004 revision. United Nations Population Division, Department of Economic and Social Affairs. http://esa.un.org/unpp. accessed 9/1/06.

UNDP, 2003. Human Development Report 2003-Millennium Development Goals: A Compact Among Nations to End Poverty. UNDP, New York.

Weitz, A., Franceys, R., 2002. Beyond Boundaries: Extending Services to the Urban Poor. Asian Development Bank, Manila.

WHO/UNICEF, 2000. Global Water Supply and Sanitation Assessment Report 2000. Joint Monitoring Programme. WHO, Geneva.

WHO/UNICEF, 2006. Meeting the MDG Drinking Water and Sanitation TarGeneva. taining Utility Services for the Poor. World Bank, Washington DC. get: The Urban and Rural Challenge of the Decade. WHO and UNICEF, 